\title{
Deksripsi kesesuaian usia kronologis dan usia dentalis melalui estimasi pertumbuhan ujung akar gigi premolar
}

\author{
Inne Suherna Sasmita', Lusi Epsilawati2 ${ }^{*}$, Fadhlil Ulum Abdul Rahman³
}

\begin{abstract}
Objectives: The purpose of this study was to find out the description of chronological age and dental age suitability through estimation of root growth of maxillary and mandibular premolar teeth.

Material and Methods: This study was a descriptive study with cross-sectional approach performed on the maxillary and mandibular first and second premolars. Data was taken from 50 panoramic radiographs contained in the 2015-2016 RSGM Unpad archives. Analyzes were performed based on age predictions from the Demirjian table compared to chronological ages in several age groups. The data is then presented in tabular form.
\end{abstract}

Results: This study shows that there is a high degree of concordance between chronological age and dental age through premolars 1 and 2, both upper and lower jaws of the Demirjian table in the initial phase of tooth root formation at 8 years chronological age and at the final phase of root apex closure at 12-13 years chronological age through the assessment of panoramic radiograph.

Conclusion: Chronological age and dental age depend on the precise assessment of root growth of premolar 1 and 2 teeth in the maxillary and mandibular regions having a high degree of suitability in the early and final phases of tooth root formation which are seen more radiographically.

Keywords: Demirjian Table, root apex development, chronological and dental age

Cite this article: Sasmita IS, Epsilawati L, Rahman FIUA. Deskripsi kesesuaian usia kronologis dan usia dentalis melalui estimasi pertumbuhan ujung akar gigi premolar. Jurnal Radiologi Dentomaksilofasial Indonesia 2020;4(1)27-30. https:// doi.org/10.32793/jrdi.v4i1.476

\section{PENDAHULUAN}

Usia individu dapat ditentukan melalui berbagai cara contohnya usia kronologis, usia biologis, usia morfologis, usia skeletal, usia gigi/usia dentalis, behavioural age, mental age dan self concept age serta lainnya. ${ }^{1}$ Pada beberapa kasus, usia kronologis dan biologis seringkali menunjukkan ketidaksamaan, hal ini diduga karena perbedaan perkembangan serta perbedaan dalam variasi ras. Untuk itu berbagai parameter dikembangkan seperti usia dental, usia tulang, dan usia menta untuk dijadikan sebagai indikator terpadu dalam penentuan usia biologis dan perkembangan tubuh. ${ }^{2}$

Usia gigi atau usia dentalis merupakan faktor yang cukup berperan penting pada saat kita akan melakukan perawatan, terutama perawatan maloklusi yang berhubungan dengan stuktur kraniofasial. $^{3-5}$ Usia dentalis dapat digunakan sebagai alat untuk mengetahui usia kronologis seseorang. Banyak teknik dalan menentukan usia dentalis, salah satunya dengan memanfaatkan penilaian pertumbuhan dan perkembangan gigi. Salah satu diantaranya yang paling banyak digunakan adalah metode Demirjian (origina Demirjian method) yang merupakan metode denta age estimation yang disajikan dalam bentuk tabel perkembangan atau kalsifikasi gigi dengan setiap tahapan pertumbuhan gigi diberikan skor yang berbeda. Metode ini secara teoritis awalnya mengklasifikasikan fase perkembangan gigi menjadi delapan tahap perkembangan dimulai dari pembentukan mahkota, akar, hingga tertutupnya apeks akar gigi pada hanya tujuh gigi rahang bawah yang kemudian dikonversi dari data skor maturase gigi ke dalam tabel usia dentalis Demirjian. Pada perkembangan berikutnya beberapa penelitian telah memodifikasi dan mengadopsi metode tabel Demirjian juga untuk gigi geligi rahang atas dan melibatkan gigi molar ketiga (wisdom teeth). ${ }^{6-12}$

Pertumbuhan gigi dapat ditentukan berdasarkan pertumbuhan akar dan tingkat kalsifikasi dari ujung akar. Penelitian terdahulu menjelaskan bahwa waktu erupsi gigi tidak akurat dalam menentukan usia gigi karena erupsi gigi dipengaruhi oleh banyak faktor. ${ }^{5}$ Faktor tersebut diantaranya faktor lingkungan, faktor ketersediaan ruang pada lengkung gigi dan lengkung rahang, waktu ekstraksi gigi sulung, impaksi gigi, atau hal lainnya yang dapat mempengaruhi proses erupsi. ${ }^{5}$ Metode Demirjian dikatakan memiliki keakuratan sangat tinggi hal ini terbukti dalam penelitian yang pernah dilakukan, penelitian dilakukan pada anakanak, dan hasilnya terlihat bahwa terdapat kesesuaian antara usia kronologis terhadap usia pertumbuhan gigi melalui observasi ujung akar 
berdasarkan tabel Demirjian. ${ }^{13}$

Gigi premolar merupakan gigi dengan lokasi pertumbuhan diantara gigi depan (insisif) dan gig belakang (molar) memiliki pola pertumbuhan cenderung lebih lambat dibandingkan gigi yang lain di dalam mulut, selain itu beberapa literatur menyebutkan bahwa gigi ini jarang sekal mengalami kondisi impaksi. Hal ini dapat berguna untuk memberikan variasi gambaran penilaian usia dentalis dalam rentang usia peralihan dari anakanak ke fase usia remaja antara 8 sampai 13 tahun Adapun tujuan dari studi ini adalah untuk melihat gambaran kesesuaian antara usia kronologis terhadap usia dental dengan cara melihat dari pertumbuhan ujung akar gigi $\mathrm{P} 1$ dan $\mathrm{P} 2$ rahang atas dan bawah sesuai dengan tabel Demirjian.

\section{BAHAN DAN METODE}

Penelitian ini adalah penelitian deskriptif dimana hasil yang diperoleh berupa data kuantitatif. ${ }^{4}$ Populasi yang digunakan adalah semua data dari pertumbuhan gigi premolar 1 dan 2 yang berasal dari radiografi panoramik dari pasien yang berusia 8-13 tahun (6 kelompok), sehingga tota sampel pada tiap usia berjumlah 50 buah radiograf panoramik dan total panoramik yang digunakan 300 buah panoramik. Data dikumpulkan dan dianalisis berdasarkan 5 kriteria berikut di bawah ini yang telah digambarkan pada Gambar 1.

Tahap 1, pembentukan crown selesai dan tampak awal pembentukan akar yang terlihat dalam bentuk spicule; Tahap 2, crown sempurna dan akar baru terbentuk kurang dari $1 / 3$ bagian; Tahap 3, crown sempurna dan akar sudah terbentuk $1 / 3$ bagian; Tahap 4, crown sempurna dan akar telah terbentuk lebih dari $1 / 3$ bagian akan tetapi bagian foramen apikal belum tertutup; Tahap 5, crown sempurna, akar telah terbentuk lebih dar $1 / 3$ bagian akan tetapi bagian foramen apikal tertutup secara baik.

Data dari tiap kelompok kemudian dicatat dan dikumpulkan, kemudian disesuaikan antara usia dental seperti pada tabel dan usia kronologis dari pasien pada saat pemaparan teknik radiografi.

\section{HASIL}

Hasil penelitian terhadap pertumbuhan akar gigi premolar pertama dan kedua rahang atas dan rahang bawah berdasarkan usia melalui penilaian pada radiograf panoramik diperoleh data sebagaimana yang terdapat dalam Tabel 1.

Tabel 2 menunjukkan pertumbuhan ujung akar gigi premolar rahang atas berdasarkan staging tabel Demirjian serta kesesuaiannya dengan usia kronologis sampel. Untuk gigi P1 pada usia kronologis 8 tahun didominasi kategori 1 dengan distribusi 30 gigi, sedangkan pada P2 juga pada kategori 2 dengan distribusi 26 gigi. Pada usia kronologis 9 tahun lebih banyak pada kategori 3 untuk gigi P1 dan kategori 3 serta kategori 4 untuk gigi P2. Pada usia kronologis 10 tahun gigi P1 dan P2 lebih banyak pada kategori 4 dengan jumlah 32 gigi P1 dan 26 gigi P2. Pada usia kronologis 11 tahun untuk gigi P1 terlihat lebih banyak pada kategori 3 sedangkan gigi P2 pada kategori 4. Untuk usia 12 dan 13 tahun baik pada gigi P1 dan gigi P2 masingmasing pada kategori 4 dan 5 . Berdasarkan usia dentalis, menurut tabel Demirjian dengan usia kronologis pada gigi P1 terdapat kesesuaian yang paling mendekati pada usia kronologis 8 tahun yang mendekati usia dentalis antara 7/7,5 tahun, usia kronologis 12 tahun yang mendekati dengan usia dentalis antara $12,7 / 13,4$ tahun, dan usia kronologis 13 tahun yang mendekati dengan usia dentalis 13,5/14,1 tahun, sedangkan untuk gigi P2 hampir semuanya memiliki rentang perbedaan yang cukup jauh antara usia kronologis dan usia dentalis, hanya pada kisaran usia kronologis 12 tahun yang paling mendekati usia dentalis 13,2/13,8 tahun.

Tabel 3 memperlihatkan pertumbuhan ujung akar gigi premolar rahang bawah berdasarkan staging tabel Demirjian. Untuk gigi P1 pada usia kronologis 8 tahun didominasi kategori 1 dengan distribusi 35 gigi, sedangkan pada P2 juga pada kategori 1 dengan distribusi 32 gigi. Pada usia kronologis 9 tahun lebih banyak pada kategori 3 untuk gigi P1 dan gigi P2. Pada usia kronologis 10 tahun gigi P1 dan P2 lebih banyak pada kategori 4 dengan jumlah 28 gigi $\mathrm{P} 1$ dan 32 gigi $\mathrm{P} 2$. Pada usia

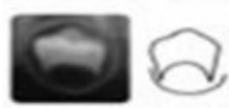

1

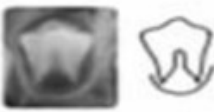

2

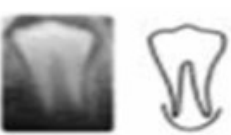

3
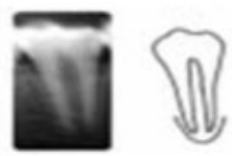

4
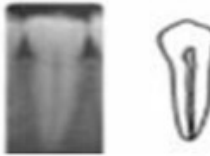

5

Gambar 1. Ilustrasi gambaran dari 5 kategori yang digunakan dan dipilih berdasarkan metode Demirjian

Tabel 1. Distribusi usia sesuai dengan stage pada gambar berdasarkan tabel Demirjian

\begin{tabular}{ccc}
\hline Stage & $\mathbf{P 1}$ & $\mathbf{P 2}$ \\
\hline $\mathbf{1}$ & $7 / 7,5$ & $9,7 / 10.6$ \\
\hline $\mathbf{2}$ & $11 / 11,8$ & $12 / 12,7$ \\
\hline $\mathbf{3}$ & $12,3 / 13,1$ & $12,8 / 13,5$ \\
\hline $\mathbf{4}$ & $12,7 / 13,4$ & $13,2 / 13,8$ \\
\hline $\mathbf{5}$ & $13,5 / 14,1$ & $14,4 / 14,6$ \\
\hline
\end{tabular}


Tabel 2. Gambaran pertumbuhan akar gigi pada rahang atas berdasarkan kesesuaian usia kronologis dan staging usia dentalis menurut Demirjian

\begin{tabular}{|c|c|c|c|c|c|c|c|c|c|c|}
\hline \multirow{3}{*}{$\begin{array}{c}\text { Usia } \\
\text { Kronologis }\end{array}$} & \multicolumn{10}{|c|}{ Staging Usia Dentalis } \\
\hline & \multicolumn{5}{|c|}{ Gigi Premolar Pertama } & \multicolumn{5}{|c|}{ Gigi Premolar kedua } \\
\hline & 1 & 2 & 3 & 4 & 5 & 1 & 2 & 3 & 4 & 5 \\
\hline 8 & 30 & 20 & 0 & 0 & 0 & 24 & 26 & 0 & 0 & 0 \\
\hline 9 & 0 & 21 & 24 & 14 & 0 & 0 & 2 & 24 & 24 & 0 \\
\hline 10 & 0 & 0 & 18 & 32 & 0 & 0 & 0 & 24 & 26 & 0 \\
\hline 11 & 0 & 0 & 36 & 14 & 0 & 0 & 0 & 24 & 26 & 0 \\
\hline 12 & 0 & 0 & 0 & 36 & 14 & 0 & 0 & 0 & & 12 \\
\hline 13 & 0 & 0 & 0 & 12 & 38 & 0 & 0 & 0 & 10 & 40 \\
\hline
\end{tabular}

Tabel 3. Gambaran pertumbuhan akar gigi pada rahang bawah berdasarkan kesesuaian usia kronologis dan staging usia dentalis menurut Demirjian

\begin{tabular}{|c|c|c|c|c|c|c|c|c|c|c|}
\hline \multirow{3}{*}{$\begin{array}{c}\text { Usia } \\
\text { Kronologis }\end{array}$} & \multicolumn{10}{|c|}{ Staging Usia Dentalis } \\
\hline & \multicolumn{5}{|c|}{ Gigi Premolar Pertama } & \multicolumn{5}{|c|}{ Gigi Premolar Kedua } \\
\hline & 1 & 2 & 3 & 4 & 5 & 1 & 2 & 3 & 4 & 5 \\
\hline 8 & 35 & 13 & 2 & 0 & 0 & 32 & 15 & 3 & 0 & 0 \\
\hline 9 & 0 & 10 & 28 & 14 & 0 & 0 & 12 & 30 & 8 & 0 \\
\hline 10 & 0 & 0 & 20 & 28 & 2 & 0 & 0 & 18 & 32 & 0 \\
\hline 11 & 0 & 0 & 10 & 20 & 10 & 0 & 0 & 18 & 26 & 12 \\
\hline 12 & 0 & 0 & 0 & 10 & 40 & 0 & 0 & 0 & 20 & 30 \\
\hline 13 & 0 & 0 & 0 & 6 & 44 & 0 & 0 & 0 & 18 & 32 \\
\hline
\end{tabular}

kronologis 11 tahun untuk gigi P1 terlihat lebih banyak pada kategori 4 sedangkan gigi $\mathrm{P} 2$ juga pada kategori 4. Untuk usia 12 dan 13 tahun baik pada gigi P1 maupun pada gigi P2 didominasi kategori 5. Berdasarkan usia dentalis menurut tabel Demirjian dengan usia kronologis pada gigi P1 terdapat kesesuaian yang paling mendekati pada usia kronologis 8 tahun yang mendekati usia dentalis antara $7 / 7,5$ tahun, usia kronologis 12 tahun yang mendekati dengan usia dentalis antara 12,7/13,4 tahun, dan usia kornologis 13 tahun yang mendekati dengan usia dentalis 13,5/14,1 tahun Sedangkan untuk gigi P2 hampir semuanya memiliki rentang perbedaan yang cukup jauh antara usia kronologis dan usia dentalis, hanya pada kisaran usia kronologis 12 tahun yang paling mendekati usia dentalis $13,2 / 13,8$ tahun.

Pola kesesuaian antara usia kronologis dan usia dentalis berdasarkan tabel Demirjian baik pada regio rahang atas maupun regio rahang bawah terlihat memiliki kesamaan pola antara gig premolar di mana kesesuaian usia yang paling mendekati terutama berada pada fase awal pembentukan akar yaitu pada kisaran usia kronologis 8, 12 dan 13 tahun. Sedangkan usia antara 9-11 tahun terlihat perbedaan usia kronologis dan usia dentalis berada pada rentang yang cukup jauh mencapai lebih dari 1,5 tahun.

\section{DISKUSI}

Perkembangan gigi dan tulang secara fisiologis dapat membantu untuk menentukan usia, dimana hal ini sangat diperlukan untuk rencana perawatan seperti intervensi ortodontik, ortopedi, atau tindakan klinis lainnya. Selain sangat diperlukan dalam berbagai pertimbangan rencana perawatan dan intervensi klinis, usia kronologis dari pasien juga sangat penting dalam hal kepentingan pemeriksaan forensik. ${ }^{6}$ Perkembangan gigi kurang dipengaruhi oleh kualitas lingkungan dari pembangunan skeletal. ${ }^{6}$ Beberapa metode telah dilakukan untuk keperluan ini, yang umumnya disebut sebagai metode penilaian maturasi gigi termasuk metode tabel Demirjian dengan pemberian skor pada setiap fase perkembangan gigi dan telah diterima secara luas penggunaannya. ${ }^{6-9}$

Penentuan usia kronologis dalam hal kepentingan forensik cukup sulit bila ditinjau dari segi erupsi gigi. ${ }^{6}$ Oleh karena itu, cara terbaik yaitu dengan menilai usia gigi melalui tahap perkembangannya atau tahap kalsifikasinya. ${ }^{7}$ Metode delapan tahap Demirjian adalah salah satu metode yang digunakan untuk mengukur tingkat maturasi gigi dari usia 3-17 tahun. ${ }^{1}$ Metode Demirjian terbukti memiliki akurasi tinggi dan sangat berkorelasi dengan usia kronologis. Walaupu begitu, belum ada metode dapat secara akurat menentukan usia secara tepat, karena adanya variasi dalam tiap individu. Hal ini karena perbedaan usia kronologis dan usia dentalis dapat dikaitkan dengan berbagai faktor, termasuk ketepatan metode, pemeriksaan, pengalaman pengamat, jumlah sampel dan distribusi. ${ }^{7,9}$

Dalam penelitian ini terlihat berbagai variasi dari pola perkembangan dan maturasi akar gigi premolar 1 dan 2 rahang atas dan rahang bawah 
pada kelima kategori berdasarkan tabel Demirjian. Namun, terlihat pola yang sama antara gigi premolar 1 rahang atas dan rahang bawah dalam hal kesesuaian hasil penilaian usia dentalis dengan usia kronologis yang menunjukkan bahwa usia dentalis sangat mendekati usia kronologis pada saat fase awal pembentukan akar di usia 8 tahun dan pada fase akhir pembentukan akar mencapai lebih dari $1 / 3$ bagian menjelang apeks akar tertutup yaitu dalam kisaran usia 12 sampai 13 tahun. Hal ini dimungkinkan oleh faktor presisi dalam metode penilaian pertumbuhan akar yang lebih jelas terlihat pada fase awal pembentukan dan fase akhir menjelang tertutupnya apeks akar sementara, sedangkan pada fase pertumbuhan akar setelah fase awal yang pada penelitian ini pada stage 2 dan 3 terlihat rentang yang jauh antara usia kronologis dan usia dentalis. Hasil ini sejalan dengan yang diungkapkan Maber et al. dan Khanjal et al. bahwa penilaian pada fase pertumbuhan akar lanjut biasanya akan lebih sulit. ${ }^{14,15}$ Selain itu, penelitian dari Kermani et al. juga memperlihatkan hasil yang sebagian sejalan dengan penelitian ini yaitu kesesuaian yang paling mendekati antara usia kronologis dan usia dentalis diamati pada rentang usia 11 hingga 13 tahun, namun memilik ketidaksesuaian pada usia 7-9 tahun. ${ }^{16}$ Perbedaan ini dapat disebabkan karena adanya variasi etnis dan populasi penelitian serta jenis kelamin yang diabaikan pada penelitian ini. Adapun pola pertumbuhan akar gigi premolar 1 dan 2 baik pada regio rahang atas dan rahang bawah memperlihatkan pola yang serupa dalam kesesuaian usia kronologis dan usia dentalis.

\section{SIMPULAN}

Usia kronologis dan usia dentalis bergantung pada presisi penilaian pertumbuhan akar gigi premolar 1 dan 2 pada regio rahang atas dan rahang bawah memiliki tingkat kesesuaian yang tinggi pada fase awal dan akhir pembentukan akar gigi yang secara radiograf lebih jelas terlihat.

\section{DAFTAR PUSTAKA}

1. Stewart RE, Barber TK. Pediatric dentistry, 1st ed. 2016. USA, CV. Mosby Company.

2. McKenna CJ, James H, Taylor JA, Townsend GC. Tooth development standards for South Australia. Aust Dent J 2002;47:223-7.

3. Demirjian, H. Goldstein, and J.M. Tanner.. A new system of dental age assessment : Human Biology, 1973. vol. 45, no. 2, pp. 211-227

4. R. J. Hegde and P. B. Sood. Dentalmaturity as an indicator of chronological age: radiographic evaluation of dental age in 6 to 13 years children of Belgaumusing Demirjian methods, Journal of the Indian Society of Pedodontics and PreventiveDentistry, 2002. vol. 20, no. 4, pp. 132-138.

5. G.Willems, A. Van Olmen, B. Spiessens, and C. Carels. Dental age estimation in Belgian children: Demirjian's technique revisited. Journal of Forensic Sciences, 2001.vol. 46, no. 4, pp. 893-895.

6. G. Willems. A review of the most commonly used dental age estimation techniques. Journal of ForensicOdontoStomatology. 2001. vol. 19, no. 1, pp. 9-17.

7. Jain V, Kapoor P, Miglani R. Demirjian approach of dental age estimation: abridged for operator ease. Journal of Forensic dental sciences 2016. Vol. 8, no.3, pp.

8. Ali AMM, Ahmed WH, Khattab NM. Apllicability of Demirjian's method for dental age estimation in a group of Egyptian children. BDJ OpeN 2019. Vol 5, no.2, pp.

9. Gupta R, Rajvanshi H, Effendi H, Afridi S, Vuyyuru KK, Vijay B, et al. Dental age estimation by Demirjian's and Nolla's method in adolescents of Western Uttar Pradesh.

10. U. H. Agg, L. Matsson. Dental maturity as an indicator of chronological age: the accuracy and precision of three methods. European Journal of Orthodontics, 2010. vol. 7, no. 1, pp. 25-34, 1985.Sci Int. 2010, Apr.197(1-3):121.e1-4.

11. Lee SE, Lee SH, Lee JY, Park HK, Kim YK. Age estimation of Korean children bases on dental maturity. Forensic Science International 2008. Vol. 178. Pp. 125-131

12. Lewis AJ, Boaz, K, Nagesh KR, Srikant N, Gupta N, Nandita KP, et al. Demirjian's method in the estimation of age: A study on human third molar. J Forensic Dent Sci 2015. Vol.7. No.2. pp 153-157

13. H.Cardoso. Differential sensitivity in growth and development of dental and skeletal tissue to environmental quality Arquivos de Medicina, 2007. vol. 21, no. 1, pp. 19-23.

14. M. Maber, H.M. Liversidge, M.P. Hector, Accuracy of age estimation of radiographic methods using developing teeth, Forensic Sci. Int 2006. S68-S73.

15. K.S. Dhanjal, M.K. Bhrdwaj, H.M. Liversidge, Reproducibility of radiographic stage assessment of third molars, Forensic Sci. Int. 2006. 159.S74-S77.

16. Kermani M, Yazdi FT, Haghighi MA. Evaluation of the accuracy of Demirjian's method for estimating chronological age from dental age in Shiraz, Iran: using geometric morphometric method. Clin Exp Dent Res 2019. Vol 5.pp 191-198. 